\title{
Pozitif örgütsel davranışın örgütsel bağlılık üzerindeki etkisi ${ }^{1}$
}

\author{
Effect of positive organizational behaviour on \\ organizational commitment
}

\section{Zeynep Mert}

Psikolog, Tezli Yüksek Lisans Öğrencisi, Kırıkkale Üniversitesi, Sosyal Bilimler Enstitüsü, Yönetim ve Organizasyon Bölümü, Tezli Yüksek Lisans Programı, TÜRKIYE, e-mail: zeeynepmert17@gmail.com

Öz

Bu çalışmanın amacı; örgütsel alanda yeni bir konu olan pozitif örgütsel davranışın, literatürde pek çok araştırma yapılmış örgütsel bağlılık üzerinde etkisi olup olmadığını belirlemektir. Araştırmanın örneklemini İstanbul ilinde faaliyet gösteren beş farklı imalat işletmesinde çalışan 179 kişi oluşturmaktadır. Araştırmada veri toplama yöntemi olarak anket yöntemi kullanılmıştır. Anket formu üç bölümden oluşmaktadır. İlk bölümde demografik bilgiler, ikinci bölümde pozitif örgütsel davranış ölçeği, üçüncü bölümde ise örgütsel bağlllık ölçeği yer almaktadır. Araştırma sonucu elde edilen veriler istatistiksel olarak analiz edilmiştir. Bu analizler frekans dağılımı, korelasyon analizi ve basit doğrusal regresyon analizidir. Korelasyon analizi sonucunda, pozitif örgütsel davranış ve örgütsel bağlllık arasında pozitif yönlü, istatistiksel açıdan anlamlı bir ilişki olduğu bulunmuştur. Ayrıca basit doğrusal regresyon analizine göre; pozitif örgütsel davranış ve örgütsel bağlılık arasında istatistiksel açıdan anlamlı, pozitif bir ilişki olduğu belirlenmiştir.

Anahtar kelimeler: pozitif psikoloji, pozitif örgütsel davranış, örgütsel bağlılık

\begin{abstract}
The purpose of this study is to determine whether positive organizational behavior, which is a new subject in the organizational field, has an effect on organizational commitment, which has been researched in the literature. The sample of the study consisted of 179 employees working in five different manufacturing companies in Istanbul. Survey technique was used as data collection technique in the research. The questionnaire form consists of three parts. The first part includes demographic information, the second part includes the positive organizational behavior scale, and the
\end{abstract}

${ }^{1} \mathrm{Bu}$ makale yüksek lisans tezinden çıkarılmıştır.

Citation/Atıf: MERT, Z. (2021). Pozitif örgütsel davranışın örgütsel bağlllık üzerindeki etkisi. Journal of Original Studies. 2(2), 69-77, DOI: 10.47243/jos.2.2.01

Corresponding Author/ Sorumlu Yazar: Zeynep Mert

E-mail: zeeynepmert17@gmail.com
Bu derginin içerĭ̆ $\mathrm{i}$ Creative Commons Attribution-NonCommercial 4.0 Uluslararası Lisansı altında lisanslanmıştır.

Content of this journal is licensed under a Creative Commons Attribution-NonCommercial 4.0 International License. 
third part includes the organizational commitment scale. The data obtained as a result of the research were analyzed statistically. These analyzes are frequency distribution, correlation analysis and simple linear regression analysis. As a result of the correlation analysis, it was found that there is a positive, statistically significant relationship between positive organizational behavior and organizational commitment. In addition, according to simple linear regression analysis; It was determined that there is a statistically significant and positive relationship between positive organizational behavior and organizational commitment.

Keywords: positive psychology, positive organizational behavior, organizational commitment

\section{GİRIŞ}

Psikoloji biliminin odak noktası uzun yıllar boyunca psikolojik hastalıklar ve kişilerin olumsuz yanları olmuştur. Psikolojinin başlangıçtaki amaçları salt bu olmasa da II. Dünya Savaşı, ekonomik buhranlar gibi o dönemin durumsallığ Ancak Seligman (1998) insanların olumlu yönlerine odaklanmayı ve bu özellikleri geliştirmeyi öne sürmüştür. Seligman ve arkadaşları ile başlayan bu yeni fikir akımının temelleri 2000'lerin başında atılmıştır. Psikolojinin yeni bir dalı olan "pozitif psikoloji" oldukça ses getirmiştir. Pozitif psikologlara göre, pozitif psikolojinin amac1, odağı bireylerin yanlışlarından alıp doğrularına; zayıf taraflarından alıp güçlü yanlarına yöneltmektir.

Pozitif psikolojinin örgütsel davranış alanına yansıması "pozitif örgütsel davranış" olarak adlandırılmaktadır. Pozitif örgütsel davranış kısaca, çalışanların eksik yönlerini değil güçlü yönlerini öne çıkarmayı ifade etmektedir. Pozitif örgütsel davranış ile beraber örgütsel sermaye türlerine (geleneksel ekonomik sermaye, beşeri sermaye ve sosyal sermaye) psikolojik sermaye eklenmiştir. Psikolojik sermaye dört bileşenden oluşmaktadır: umut, öz yeterlik, iyimserlik ve psikolojik dayanıklılık. Bu dört bileşene sahip çalışanlar başarılı ve motivasyonludur. Dolayısıyla psikolojik sermayesi yüksek çalışanlar, örgütlerine rekabet avantajı sağlamaktadır. Ancak örgütler için bu çalışanları bünyesine katmak kadar gelişimlerini sağlamak da önemlidir. Pozitif örgütsel davranış bunu amaçlamaktadır.

Örgütsel bağlılık kapsamında birçok çalışma yapılmıştır. Bu çalışmada örgütsel alanda görece yeni bir konu olan pozitif örgütsel davranış çerçevesinde örgütsel bağlılığın incelenmesi, pozitif örgütsel davranış ile örgütsel bağlılık arasında ilişki olup olmadığı, varsa ilişkilerin yönünü ve gücünü belirlemek amaçlanmaktadır. Araştırmanın yapılacağı sektör olarak imalat sektörü seçilmiştir. Bu bağlamda çalışmanın hipotezleri şu şekildedir:

H1: Pozitif örgütsel davranış ve örgütsel bağlılık arasında ilişki vardır.

H2: Pozitif örgütsel davranışın örgütsel bağlılık üzerinde etkisi vardır.

\section{KAVRAMSAL ÇERÇEVE}

\subsection{Pozitif Örgütsel Davranış}

Hızla değișen dünyada insan odaklı yönetim şekilleri artmaktadır. Çalışanlarına değer veren işletmelerin rekabet avantaj1 elde etmesi bunun nedenlerinden biridir. Örgütlerinin fikirlerine, bir birey olarak kendilerine önem verildiğini algılayan çalışanların iş tatmini, performans, örgütsel bağlllıklarının arttığ1 çeşitli araştırmalarla kanıtlanmıştır.

Pozitif Örgütsel Davranış, Fred Luthans (2002) ve Thomas Wright (2003)'ın öncülüğünde, “örgütsel davranışa pozitif bakış açısı" katan bir akımdır. Luthans (2002a) pozitif örgütsel davranışı; örgütlerde performansı iyileştirmek için pozitif yönelimli, ölçülebilen, geliştirilebilen ve yönetilebilen, insan kaynaklarına ilişkin çalışma ve uygulama, şeklinde tanımlamıştır. Pozitif örgütsel davranışı savunan araştırmacılar, örgütlerin başarıyı yakalayabilmesi için örgütsel davranışlara pozitif bir pencereden bakılması gerektiğini vurgulamaktadır.

Pozitif düşünceler, kavramlar aslında birçok kişisel gelişim kitabına, çok satan kitaplara konu olmuştur. Ancak teorik bir alt yapısı ve araştırmaları yoktur. Pozitif örgütsel davranışın diğer popüler pozitifçi düşüncelerden ayrılabilmesi için, ölçülebilme kriterine yani teori ve araştırmalara sahip olması gerekmektedir (Luthans, 2002a: 57).

Örgütsel alanda genel kabul gören pozitif örgütsel davranış için belirlenmiş beş kapsam kriteri vardır (Luthans, Youssef ve Avolio, 2007):

1. Kavramlar teori ve araştırma temelli olmalıdır.

2. Özellikle insan kaynakları alanında performansa etki etmelidir.

3. Geçerlik ve güvenirliği test edilmiş ölçme araçları olmalidir.

4. Kavramlar olumlu yönleri içermelidir. 
5. Kavramlar trait-like değil, state-like olmalıdır; değişime ve gelişime açık olmalıdır.

Pozitif örgütsel davranış psikolojik sermayeyi ve dört boyutunu içermektedir. Bu boyutlar; öz yeterlik, iyimserlik, umut ve psikolojik dayanıklılıktır.

\subsection{1. Öz Yeterlik}

Öz yeterlik kavramı ilk kez Bandura (1986) tarafından tanımlanmıştır. Bandura (1994) öz yeterliği, "bireyin, belli bir performansı göstermek için gereken faaliyetleri planlayıp, başarma yetenekleri hakkında kendine olan inancı" şeklinde tanımlamaktadır (akt. Aşkar ve Umay, 2001: 1). Bandura'ya göre bu inançlar bireyin herhangi bir alandaki davranışlarının etkileri veya sonuçları hakkında beklentilerini etkilemektedir. Zira bireyin yeteneklerine inancı yoksa süreç içinde daha az çaba sarf edecektir.

Stajkovic ve Luthans (1998) öz yeterliği, bireyin, spesifik bir işi (ödevi) başarıyla tamamlamaya yönelik bilişsel kaynaklarına, motivasyonuna ve becerilerine olan inancı şeklinde tanımlamaktadır.

Öz yeterlik tanımındaki anahtar nokta, öz yeterliğin göreve ve duruma özgü olmasıdır. Dolayısıyla öz yeterlik, liderlere ve çalışanlara verilen duruma özel görevlerle geliştirilebilmektedir (Luthans, 2002b: 63). Bandura'ya göre bireyin öz yeterliğinin gelişmesinde görev alan dört kaynak bulunmaktadır:

1. Ustalık deneyimleri: Bireyler yaptıkları eylemlerin etkililiğini değerlendirip öz yeterliklerini buna göre yorumlamaktadırlar. Başarılı olarak yorumlanan durumlar öz yeterlik inancını artırırken, başarısız olarak yorumlanan deneyimler öz yeterlik inancını düşürmektedir.

2. Dolaylı deneyimler: Birey model aldığı kişinin pekiştirilen davranışını gördüğünde aynı davranış, bireyde de pekiştirilmektedir. Benzer şekilde, modelinin bir davranıştan dolayı cezalandırıldığını görürse, birey de o davranıştan kaçınma eğilimi gösterecektir. Bu noktada rol model ile bireyin özellikleri ne kadar örtüşürse dolaylı deneyimler kaynağı o kadar etkili olmaktadır (Erkutlu, 2015: 79).

3. Sözel ikna: Bireylerin güvendikleri kişilerden gelen, görevi başarabileceklerine dair sözlerdir. Bu ikna edici sözler bireylerin öz yeterlik inancını olumlu yönde etkilemektedir. İşverenler, yöneticiler, liderler çalışanlarını, verilen görevleri ve işleri başarıyla yapabilecekleri konusunda yeterli olduklarına inandırmalı ve başarılarını onaylamalıdır.

4. Fiziksel ve duygusal uyarılma: Olumlu ruh hali bireylerin öz yeterlik inançlarını artırırken, olumsuz ruh hali öz yeterliklerinin azalmasına sebep olmaktadır. Bu nedenle, bireyleri olumsuz ruh halinden arındırmak öz yeterliği artırma yöntemlerinden biridir (Bandura, 1994).

Örgütlerözyeterliğin, çalışanlarınbaşarılarıüzerindeki etkisini gözden kaçırmamalıdır. Çalışanların var olan öz yeterliklerinin geliştirilebilmesi için bu dört kaynaktan yararlanılabilir.

\subsection{2. İyimserlik}

Literatürde iyimserliğin yapılmış birçok tanımı bulunmaktadır. Scheir ve Carver (1985: 26)'a göre iyimserlik, genellenmiş olumlu sonuç beklentileridir. Goleman (2009: 128) iyimserliği, hayatın tüm zorluklarına rağmen, yaşamda her şeyin iyi gideceğine olan inanç, beklenti ve duygu, olarak tanımlamaktadır.

İyimserlik düzeyi yüksek bireyler düşük olan bireylere oranla daha etkili başa çıkma yöntemleri kullanma eğilimindedir (Grotkowski ve Miller, 2019: 1). Örgütsel alana bakıldığında iyimser çalışanlar, motivasyonu ve beklentileri yüksek, olumlu hedefleri olan, güçlükler karşısında azimli bireylerdir (Çalışkan ve Erim, 2010: 265).

Çalışanların iyimserliklerinin geliştirilmesi için geçmişte yaşanan başarısızlıklar reel çerçevede değerlendirilmelidir. $\quad \mathrm{Bu}$ değerlendirmede; çalışanların olumsuz olaylardaki sorumlulukları yok sayılmamalı ancak çok fazla üzerinde durmadan olumlu olaylara odaklanmaları sağlanmalıdır (Battal, 2013; akt. Erkutlu, 2015: 142).

Pozitif Örgütsel Davranış içinde gerçekçi iyimserlikten bahsedilmektedir (Luthans, 2002a: 65). Gerçekçi iyimserlik, bireylere olayları hem iyimser hem kötümser açıklamaya ve bu açıklama stillerini duruma adapte etmeye imkân sağlamaktadır (Luthans ve Youssef, 2004: 156).

\subsubsection{Umut}

Pozitif psikolog Rick Snyder (2000), umudu; araçlar ve yollardan oluşan, başar hissine ulaşmak üzerine temellenmişbilişsel bir durum olarak tanımlamaktadır. Tanımdan da anlaşılacağı üzere Snyder umudun iki boyutlu olduğunu savunmuştur: araçlar ve yollar. Umudun ilk ögesi amaca ulaşmaya yönelik azimdir (araçlar). İkinci ögesi ise amaca ulaşmadaki yolların planıdır (yollar).

Staats ve Stassen (1985) ise umudu; geleceğe yönelik olumlu beklentilerin olumsuz beklentilerden yüksek olması, şeklinde tanımlamıştır. Bireylerin hedeflere 
sahip olması onları motive etmektedir. Bu hedeflere giden yolda engellerle karşılaştıklarında takip edecekleri alternatif yollar yaratmaları gerekmektedir. Eş deyişle, umut düzeyi yüksek bireyler hedeflerine başarıyla ulaşabilmek için hem irade gücüne hem de yöntemlere sahiptir (Luthans, Youssef ve Avolio, 2007: 63; akt. Erkutlu, 2015: 17).

Literatürdeki çalışmalarda, umut düzeyi yüksek bireylerin, umut düzeyi düşük bireylere göre daha fazla alternatif yollar bulabildikleri kanıtlanmıştır (Kutanis ve Yıldız, 2014: 147). Umut düzeyi yüksek kişilerin hedefleri nettir, insanlarla kolayca etkileşime girerler ve değişimlere kolay adapte olmaktadırlar (Luthans, 2002a: 62).

Umutla ilgili yapılan araştırmalarda, liderlerin umut düzeylerinin; işletmedeki finansal performansa, çalışanların iş tatminine ve çalışanların örgütte çalışmaya devam etmelerine anlamlı ve pozitif yönlü etkisinin olduğu belirlenmiştir (Luthans ve Youssef, 2004: 153). Luthans (2002a: 63-64) işletmelerde umudu geliştirmek ve yönetmek için bazı öneriler sunmaktadır:

- Amaç belirleme (Belirli hedefler koymak)

- Kademelendirme (Hedefleri belirginleştirmek, adım adım küçük başarılarla ilerlemek)

- Katılımcı inisiyatifi (Çalışanların, örgütlerinin bugününde ve geleceğinde kendi kontrolleri olduğunu hissetmesi)

- Yöneticilerin çalışanlarına güvendiğini göstermesi, onları cesaretlendirmesi

- Hazırlıklı olma (Umudun yollarını veya yol gücü boyutunu geliştirdiği görülmüştür.)

- Acil durum planlama (Hedeflere alternatif ve acil yollar geliştirme)

- Zihinsel prova (Belirli durumlarla ilgili zihinsel provalar yapmak)

- Yeniden hedef belirleme (Bireylerin, hedefe gidilen yolda engellerle karşılaşıldığında ne zaman ve nasıl yeni hedef belirleneceğini öğrenmeleri gerekmektedir.)

\subsubsection{Psikolojik Dayanıklılık}

Benard (1991)'e göre psikolojik dayanıklılık; stresli ve zorlu koşullarla karşılaşıldığında bireyin uyum sürecini kolaylaştıran özellikler ve koruyucu sistemler bütünüdür (akt. Erkutlu, 2015: 98). Keleş (2011: 348) ise psikolojik dayanıklılığı, bireylerin olumsuz durumlarla baş etme ve başarılı olma yeteneği olarak tanımlamaktadır.

Masten ve diğ. (1990) psikolojik dayanıklılık kavramını üç temel nitelikle açıklamıştır:
Olumsuz yaşantılara karşın var olan zorlukları aşıp beklenilenden daha fazla gelişim gösteren bireylerin ayakta kalabilmelerini sağlayan özellik. Örneğin, çok zor koşullarda büyümüş birinin ünlü olması. (2) Stresli yaşantılar (örneğin, boşanma) karşısında bireyin hızlı uyum sağlayabilme yeteneği. (3) Travmaları atlatma. Örneğin, doğal afet yaşama.

Yöneticilerin ve çalışanların psikolojik dayanıklılık kapasitelerinin etkenlik ve performans artışına pozitif etkisinin olduğu kanıtlanmıştır (Luthans, 2002b: 702). Dolayısıyla örgütler için çalışanların psikolojik dayanıklılığ1 önemlidir. Örgütlerde psikolojik dayanıklılığ1 geliştirmek için Masten (2001) üç farklı strateji önermiştir: Varlık odaklı stratejiler, risk odaklı stratejiler ve süreç odaklı stratejiler. Varlık odaklı stratejiler, risklerin varlığına rağmen, olumlu çıktıların olasılıklarını arttıran kaynaklara vurgu yapmaktadır. Varlıkları arttırarak veya güçlendirerek bireyin güçlenmesini sağlayan stratejilerdir. Risk odaklı stratejiler, istenmeyen çıktıların olasılıklarını arttıran riskleri ve stres faktörlerini azaltma üzerine odaklanmaktadır. Bireyleri riskli deneyimlerden uzak tutmayı hedefleyen stratejilerdir. Son olarak süreç odaklı stratejiler ise diğer stratejilerin aksine; bireyin yaşamını değiştirebilecek etkiler yaratmaya odaklanmaktadır (Masten ve Reed, 2002; Luthans ve Youssef, 2004: 156).

Bireylerin yaşamları boyunca karşılaşabilecekleri zorluklarınaltındankalkabilmesivehemişyerindehem de özel yaşamlarında fiziksel ve ruhsal olarak sağlıklı olabilmeleri konusunda psikolojik dayanıklılığın önemi göz ardı edilemez. Dolayısıyla yöneticilerin / işverenlerin, çalışanlarının, geliştirilebilen bir olgu olan psikolojik dayanıklılıklarını geliştirmeye yönelik çalışmalar yapmaları gerekmektedir (Jackson vd., 2007: 7; akt. Erkutlu, 2015: 115).

\subsubsection{Psikolojik Sermaye}

Global iş dünyasının karmaşıklaşması, rekabet düzeyinin artması ve teknolojik değişim ve gelişimlere uyum sağlama çabaları, bireylerin hem iş hem özel yaşamlarındaki baskıyı artırmaktadır. Bu baskı, çalışanların psikolojilerini olumsuz yönde etkilemekte ve tatminsizlik, performans düşüklüğü gibi durumlara sebebiyet vermektedir. Örgütler çalışanlarının daha verimli olmalarını sağlayabilecek yöntemleri, rekabet avantajı kazanabilecekleri sermaye türlerini incelemekte ve araştırmaktadır. Son yıllarda örgütlerin bu araştırmalarına ve ihtiyaçlarına yanıt veren yeni bir sermaye türü ortaya çıkmıştır: psikolojik sermaye. 
Tanım olarak psikolojik sermaye; (1) Zorlu görevlerde başarıya ulaşmak için gerekli çabayı göstermeyi sağlayacak güvene (öz yeterliliğe) sahip olma; (2) Şimdiki zamanda ve gelecekte başarılı olabilme ihtimaline dair pozitif yönde beklenti (iyimserlik); (3) Hedeflere ulaşma noktasında azimli olma ve başarıyı elde etmeye dönük yeni yollara yönelebilme (umut etme) ve (4) Problemlerle ya da olası sıkıntılarla yüz yüze gelindiğinde kendini toparlayabilme ve bu noktada ısrarcı bir tutum sergileyebilmedir (psikolojik dayanıklılık) (Luthans vd., 2007: 3).

Psikolojik sermaye genel olarak "kim olduğumuz" ve "pozitif gelişim sayesinde ne olabileceğimizi" belirtmektedir (Luthans, Youssef ve Avolio, 2007; Erkutlu, 2015: 132). Envick (2005) psikolojik sermayeyi "bireyin verimlilik amacıyla ekonomik, beşeri ve sosyal sermayeleri başarılı bir şekilde örgüte taşıyabilme yeteneği" şeklinde tanımlamaktadır. Psikolojik sermaye, bireylerin psikolojik olarak pozitif yönde gelişmesidir (Erkutlu, 2015: 132). Günümüz örgütlerinde, pozitif örgütsel davranış, performans geliştirmek için, pozitif odaklı insanın güçlü yönleri ve ölçülebilir, geliştirilebilir, yönetilebilir bir sermaye olan psikolojik sermaye uygulanmaktadır (Luthans ve Youssef, 2004: 152).

Psikolojik sermaye, bireylerin ne olduklarına ve gelecekte ne olacaklarına odaklanmaktadır (Erkuş ve Findıklı, 2013: 304). Psikolojik sermaye çeşitli boyutların birleşimidir. Bu boyutlar; öz yeterlik, umut, iyimserlik ve psikolojik dayanıklılıktır. Bu boyutların etkisinin her birinin toplamıyla etkileşime girip sinerji oluşturmaktadır. Ancak bütün yani psikolojik sermaye, parçaların yani umut, öz yeterlik, psikolojik dayanıklılık ve iyimserliğin toplamından daha büyüktür (Çelik vd., 2014: 564). Bu sinerji sonucunda çalışanların performansında, iyi oluş halinde, örgütsel iklimde istenilen seviyeye daha kolay ulaşılabilmektedir (Tösten ve Özgan, 2017: 869).

\section{2. Örgütsel Bağlılık}

Örgütler için mal ve hizmet üretmek ne kadar önemliyse çalışanların yaptıkları işten, çalıştıkları örgütten memnun olmaları da o kadar önemlidir. Örgütüne bağlılık duyan çalışanların işten ayrılmaları zor olmaktadır. Diğer türlü çalışan örgütünü değiştirmek isteyecek, bu da örgüt için maliyet yaratacaktır. Bu nedenle örgütlerin sahip olduğu insan kaynağı giderek daha çok önem arz etmektedir. Örgütünden memnun çalışanlar örgütü benimseyecek ve örgütün hedeflerine ulaşması için daha çok çabalayacaklardır. Burada da "örgütsel bağlılık" kavramı öne çıkmaktadır. Örgütsel bağl1lık, çalışanların örgütte kalma isteği ve örgütün amaçlarına, değerlerine olan bağlılığıdır (Doğan ve Kilıç, 2007: 38).

Mowday ve diğ. (1979: 226) örgütsel bağlllı̆̆1; çalışanların örgütün amaç ve değerlerine güçlü inancı ve kabulü, örgüt adına kayda değer çaba harcamaya isteklilik ve örgüt üyeliğini sürdürmek için güçlü bir arzu şeklinde tanımlamıştır.

Örgütsel bağlılık, çalışanın kendi çıkarları yanında örgütün çıkarlarını da düşünmesi, benimsemesi ve bu çıkarlara odaklanıp çabalamasıdır. Örgütsel bağlllık düzeyi yüksek çalışan, örgütün çıkarına olan durumlar için çabalayacak ve gönüllü olarak görev almak isteyecektir. Çalışanın bu tutumu, örgütteki diğer çalışanların da örgüte karşı pozitif bir tutum sergilemelerinde önemli bir etkendir (Sarıyıldız, 2020: 6).

Örgütler açısından bakıldığında, bağlılık, çalışanların performanslarının beklenilenden yüksek olmasını ve daha iyi iş fırsatları karşısında çalışanın örgütünden ayrılmamasını sağlamaktadır (Stup, 2006: 2). Örgütsel bağlllık düzeyi yüksek bireyler, örgütün amaçlarını isteyerek benimsemektedirler. Ayrıca bu kişiler, örgüt yararına durumlar için çabalarken üst düzey performans göstereceklerdir. Çünkü örgütsel bağlllık duygusu çalışanları içsel olarak güdülemektedir. Başka bir deyişle, biri onları denetleyeceği için üst düzey performans sergilemezler; kendileri etkinliği veya görevi başarıyla tamamlamak istedikleri için üst düzey performans göstermektedirler (Becker, 1960).

\section{YÖNTEM}

\subsection{Araştırmanın Amacı}

Araştırmanın temel amacı pozitif örgütsel davranışın örgütsel bağlılık üzerinde etkisi olup olmadığını, varsa yönünü ve derecesini tespit etmektir. Bu temel amacın yanında, pozitif örgütsel davranış boyutlarıyla örgütsel bağlılık arasındaki ilişkiyi incelemek de bu çalışmanın amaçları arasındadır.

\subsection{Araștırmanın Evreni ve Örneklemi}

Araştırmanın evrenini İstanbul ilinde faaliyet gösteren imalat işletmeleri oluşturmaktadır. $\mathrm{Bu}$ işletmelerden üç tanesi kolayda örnekleme yöntemiyle seçilmiştir. Seçilen işletmelerin imal ettiği ürünler; banyo ve mutfak armatürleri, kart ve kap1 koludur. $\mathrm{Bu}$ işletmelerin yetkilileriyle görüşülüp gerekli izinler alındıktan sonra üç şirkete toplam 400 anket dağıtılmıştır. Anketler şirkete göre farklılık gösterse de ortalama 2 hafta sonra toplanmıştır. $\mathrm{Bu}$ 
anketlerden 223 tanesi geri toplanabilmiştir. Ancak 179 tanesi değerlendirmeye uygun bulunmuştur.

179 çalışanın 36'sı kadın 143'ü erkektir. Örneklemde;
18-23 yaş arası yirmi sekiz kişi, 24-29 yaş arası otuz bir kişi, 30-35 yaş arası yirmi sekiz kişi, 36-41 yaş arası otuz yedi kişi, 42-47 yaş arası yirmi dokuz ve 48 yaş

Tablo 1. Katılımcıların Yaş Ve Cinsiyet Açısından Sıklık Ve Yüzdeliği

\begin{tabular}{lll}
\hline Cinsiyet & $\mathbf{N}$ & $\mathbf{\%}$ \\
\hline Kadın & 36 & 20,1 \\
Erkek & 143 & 79,9 \\
& & \\
Yaş & $\mathbf{N}$ & $\mathbf{\%}$ \\
\hline $18-23$ & 28 & 15,6 \\
$24-29$ & 31 & 17,3 \\
$30-35$ & 28 & 15,6 \\
$36-41$ & 37 & 20,7 \\
$42-47$ & 29 & 16,2 \\
48 ve Üzeri & 26 & 14,5
\end{tabular}

Tablo 2. Pearson Korelasyon Analizi

\begin{tabular}{|c|c|c|c|c|c|c|}
\hline & & $\begin{array}{c}\text { Pozitif } \\
\text { Örgütsel } \\
\text { Davranış }\end{array}$ & Cinsiyet & Kıdem & $\begin{array}{l}\text { Örgütsel } \\
\text { Bağlılık }\end{array}$ & Yaş \\
\hline \multirow{5}{*}{$\begin{array}{c}\text { Pozitif } \\
\text { Örgütsel } \\
\text { Davranış }\end{array}$} & Pearson & 1 & ,061 & ,106 & ,495** & ,174* \\
\hline & Correlation & & & & & \\
\hline & Sig. (2- & & ,418 & , 156 &, 000 &, 020 \\
\hline & tailed) & & & & & \\
\hline & $\mathrm{N}$ & 179 & 179 & 179 & 179 & 179 \\
\hline \multirow{4}{*}{ Cinsiyet } & Pearson & ,061 & 1 &, $227 * *$ & ,093 & ,163* \\
\hline & Correlation & & & & & \\
\hline & $\begin{array}{l}\text { Sig. (2- } \\
\text { tailed) }\end{array}$ & ,418 & & ,002 &, 218 & ,029 \\
\hline & $\mathrm{N}$ & 179 & 179 & 179 & 179 & 179 \\
\hline \multirow{4}{*}{ Kıdem } & Pearson & , 106 &, $227 * *$ & 1 & ,120 &, $650 * *$ \\
\hline & Correlation & & & & & \\
\hline & $\begin{array}{l}\text { Sig. (2- } \\
\text { tailed) }\end{array}$ & , 156 & ,002 & & ,109 &, 000 \\
\hline & $\mathrm{N}$ & 179 & 179 & 179 & 179 & 179 \\
\hline \multirow{3}{*}{$\begin{array}{l}\text { Örgütsel } \\
\text { Bağglılık }\end{array}$} & Pearson &, $495 * *$ & ,093 & , 120 & 1 & ,184* \\
\hline & $\begin{array}{c}\text { Correlation } \\
\text { Sig. (2- } \\
\text { tailed) }\end{array}$ & ,000 & ,218 & ,109 & &, 014 \\
\hline & $\mathrm{N}$ & 179 & 179 & 179 & 179 & 179 \\
\hline \multirow{3}{*}{ Yaş } & Pearson & ,174* &, $163^{*}$ &, $650 * *$ & ,184* & 1 \\
\hline & $\begin{array}{c}\text { Correlation } \\
\text { Sig. (2- } \\
\text { tailed) }\end{array}$ &, 020 & ,029 & ,000 &, 014 & \\
\hline & $\mathrm{N}$ & 179 & 179 & 179 & 179 & 179 \\
\hline
\end{tabular}


üzeri yirmi altı kişi bulunmaktadır (bkz. Tablo 1).

Tablo 2; pozitif örgütsel davranış, örgütsel bağlllık, yaş, kıdem ve cinsiyet arasındaki ilişkileri göstermektedir. Yapılan korelasyon analizi sonucunda pozitif örgütsel davranış ve örgütsel bağlılık arasında pozitif yönlü, istatistiksel açıdan anlamlı bir ilişki olduğu bulunmuştur $(r=0,495 ; \mathrm{p}<0,01)$. Ayrıca yapılan bu analiz ile pozitif örgütsel davranışın örgütsel bağlılık üzerinde etkisi olduğu belirlenmiştir. Bu durumda H1: "Pozitif örgütsel davranış ve örgütsel bağlılık arasında ilişki vardır." hipotezi desteklenmiştir.

Tablo 2 incelendiğinde, pozitif örgütsel davranış ve yaş arasında pozitif yönlü, anlamlı ilişki bulunmuştur $(r=0,174 ; p<0,05)$. Aynı şekilde, örgütsel bağlılık ve yaş arasında da pozitif yönlü, istatistiksel açıdan anlamlı ilişki olduğu belirlenmiştir $(r=0,650 ; p<0,01)$. Pozitif örgütsel davranış ve cinsiyet $(r=0,061 ; p<0,05)$, pozitif örgütsel davranış ve kıdem ( $r=0,106 ; p<0,05)$, örgütsel bağlılık ve cinsiyet $(r=0,093 ; p<0,05)$, örgütsel bağlılık ve kıdem $(r=0,120 ; p<0,05)$ arasında ilişkiler olsa da istatistiksel açıdan anlamlı değildir.

Tablo 3 incelendiğinde, bağımsız değişkenin (pozitif örgütsel davranış) bağımlı değişkendeki (örgütsel bağlılık) değişimin \%24,5'ini $\left(R^{2}=0.245\right)$ açıkladı̆̆ 1 görülmektedir.

Tablo 4 incelendiğinde; $\mathrm{p}$ değerine baktığımızda anlamlı olduğu görülmektedir $(F=57,494 ; p=, 000)$. Model anlamlı bir şekilde örgütsel bağlılığ açıklamaktadır.

Tablo 5 incelendiğinde, pozitif örgütsel davranış ve örgütsel bağlılık arasında istatistiksel açıdan anlamlı, pozitif bir ilişki vardır ( $t=7,582 ; p=0,000)$. Bu bağlamda H2:"Pozitif örgütsel davranışın örgütsel bağlılık üzerinde etkisi vardır." hipotezi kabul edilmiştir.

\section{SONUÇ VE TARTIŞMA}

İmalat işletmelerinde çalışanların pozitif örgütsel davranış ve örgütsel bağlllık düzeyleri arasındaki ilişkiyi ve bu ilişkinin yönünü ortaya koymak amacıyla

Tablo 3. Basit Doğrusal Regresyon Analizi Model Özeti

\begin{tabular}{ccccc}
\hline Model & $\mathbf{R}$ & $\mathbf{R}^{2}$ & Düzeltilmiş $\mathbf{R}^{2}$ & $\begin{array}{c}\text { Tahminin Standart } \\
\text { Hatası }\end{array}$ \\
\hline 1 &, $495^{\text {a }}$ &, 245 &, 241 &, 53547 \\
\hline
\end{tabular}

a. Yordayıcılar: (Sabit), Pozitif örgütsel davranış

Tablo 4. Basit Doğrusal Regresyon Analizi ANOVA

\begin{tabular}{rlccccc}
\hline Model & & $\begin{array}{c}\text { Kareler } \\
\text { Toplamı }\end{array}$ & df & $\begin{array}{c}\text { Ortalama } \\
\text { Kare }\end{array}$ & F & p \\
\hline 1 & Regresyon & 16,485 & 1 & 16,485 & 57,494 &, $000^{\mathrm{b}}$ \\
& Artan & 50,751 & 177 &, 287 & & \\
& Toplam & 67,236 & 178 & & &
\end{tabular}

b. Yordayıcı: (Sabit), Pozitif örgütsel davranış

Tablo 5. Basit Doğrusal Regresyon Analizi Katsayılara

\begin{tabular}{|c|c|c|c|c|c|}
\hline & \multicolumn{2}{|c|}{$\begin{array}{l}\text { Standardize } \\
\text { Edilmemiş } \\
\text { Katsayılar }\end{array}$} & \multirow{2}{*}{$\begin{array}{c}\text { Standardize } \\
\text { Katsayılar } \\
\text { Beta }\end{array}$} & \multirow[t]{2}{*}{$\mathbf{t}$} & \multirow[t]{2}{*}{ p } \\
\hline & B & Std.Hata & & & \\
\hline Sabit & 1,373 & ,248 & & 5,539 & ,000 \\
\hline $\begin{array}{c}\text { Pozitif } \\
\text { Örgüitsel }\end{array}$ & ,475 &, 063 & ,495 & 7,582 &, 000 \\
\hline Davranış & & & & & \\
\hline
\end{tabular}

a. Bağımlı Değişken: Örgütsel Bağlılık 
yapılan bu çalışmanın örneklemi İstanbul ili imalat işletmelerinde çalışan 179 işgörenden oluşmaktadır. $\mathrm{Bu}$ örneklemi oluşturan çalışanların \%79,9'u gibi büyük bir kısmı erkek çalışanlardan oluşurken \%20,1'lik kısmı kadın çalışanlardan oluşmaktadır. TÜİK Ocak 2021 verilerine göre; sanayide çalışan erkek sayısı 4.473.000, kadın sayısı 1.377 .000 olarak belirlenmiştir (TÜIK, 11.01.2021). Dolayısıyla imalat sanayi işletmelerinde uyguladığımız bu çalışmada erkek çalışan oranının yüksek çıkması beklenilen bir durumdur.

Araştırmada pozitif örgütsel davranış düzeyinin örgütsel bağlllık düzeyini olumlu yönde etkilediği bulunmuştur. Yani araştırmaya katılanların pozitif örgütsel davranış düzeyleri arttıkça örgütsel bağlılık düzeyleri de artmaktadır. Bu durum, örgütler için oldukça faydalı, istenilen bir durumdur. Çünkü pozitif örgütsel davranış düzeyi yüksek çalışan motive ve verilen görevlerde başarılı, gayretli çalışandır. Bunun yanında örgütsel bağlılığının da yüksek olması örgütlere rekabet avantajı sağlamaktadır.

Araştırmanın sonucu, Seçgin (2013)'in havacılık sektöründe uygulamasını yapmış olduğu tez çalışması ile benzeşmektedir. Seçgin (2013) tez çalışmasında, psikolojik sermaye bileşenlerinin duygusal bağlılık ve normatif bağlılı̆̆ kısmen etkilediği sonucuna ulaşmıştır.

Araştırmanın uygulandığı dönem COVID-19 pandemisi dönemidir. $\mathrm{Bu}$ bağlamda dönemi incelediğimizde; işsizliğin arttı̆̆ı, birçok firmanın, kuruluşun iflas ettiği; açık olanların toplam kapasitesinin yarısıyla çalıştığı; bazı firmaların zarar ettiği veya pandemi öncesine kıyasla daha az kâr ile çalışabildiği görülmektedir. Dolayısıyla çalışanların iş kaygısı yaşamaları olağandır. Bu nedenle ölçekleri yanlı doldurmuş olma ihtimallerini göz ardı etmemek gerekmektedir.

Araştırmanın sınırlılıklarından biri örneklemin küçük olmasıdır ( $n=179)$. Ancak tüm dünyayı etkileyen COVID-19 pandemisinde yapıldı̆̆ı için şirketlere ulaşmak ve ölçekleri uygulamak pandemi öncesine oranla zor olmuştur. Yetkili kişilerle görüşülüp izin alınan bazı şirketler pandemi döneminde çalışmamış, bazılarında ise çalışan sayısı azalmıştır. Bu durum araştırma öncesi planlanan örneklem sayısına ulaşamamaya sebep olmuştur. Sonuçta, araştırmanın sinırlılıklarından biri bu durumdur.

Ayrıca örneklemdeki cinsiyet sayılarının yakın veya eşit sayıda olmaması (kadın:36, erkek: 143) bu çalışmanın sınırlılıklarından bir diğeridir.
Bunun dişında, uygulanan ölçeklerde çalışanların araştırmanın yapıldığını bilmelerinden kaynaklanan etkilerin (Hawthorne Etkisi) de olabileceği dikkate alınmalıdır.

Sonuç olarak bu çalışmanın, çalışanların pozitif örgütsel davranış ve örgütsel bağlılık düzeyleri arasındaki ilişkileri incelemesi ve bu ilişkinin yönünü belirlemesi açısından önemli olduğu düşünülmektedir. Ayrıca bu çalışma, çalışanların pozitif örgütsel davranış ve örgütsel bağlllık düzeyleri arasındaki ilişkinin daha geniş boyutlu, daha detaylı ve evreni daha iyi temsil edecek geniş bir örneklemin olduğu farklı çalışmalarla incelenmesi konusunda teşvik edici bir araştırma olduğu düşünülmektedir. $\mathrm{Bu}$ çalışmanın, ülkemiz bağlamında yeni araştırılan pozitif örgütsel davranış literatürüne katkı sağlayacağına inanılmaktadır. Örgütler, çalışanlarının pozitif örgütsel davranış düzeylerini belirlemeli ve her bir boyutun düzeyini yükseltmek için çalışmalar yapmalıdır. Bu sayede hem çalışanlar daha verimli, motive ve gayretli çalışacak hem de örgütsel bağlılık düzeyleri yükselecektir. Sonuç olarak bu durum, örgütlere rekabet avantajı sağlayacaktır.

\section{KAYNAKÇA}

AȘKAR, P., \& UMAY, A. (2001). Perceived computer self-efficacy of the students in the elementary mathematics teaching programme. Hacettepe University Journal of Education, 21(1), 1-8.

BANDURA, A. (1994). Self-efficacy. Encylopedia of Human Behavior (Ed: V. Ramachaudran). New York: Academic Press. s. $71-81$.

BECKER, H.S (1960). Notes on the concept of commitment. Am. J. Sociol. 66: $32-40$

ÇALIŞKAN, S. C. \& ERİM, A. (2010). Pozitif örgütsel davranış değişkenleri (pod) ile yeni araştırma modelleri kurma arayışları: Pod'nin işe adanmışlık, tükenmişlik ve sinizm üzerindeki etkileri. 18. Ulusal yönetim ve organizasyon kongresi bildiriler kitabı, 658670.

ÇELIK, M., TURUNÇ, Ö., \& BİLGIN, N. (2014). Çalışanların örgütsel adalet algılarının psikolojik sermaye üzerine etkisi: çalışanların iyilik halinin düzenleyici rolü. Dokuz Eylül Üniversitesi Sosyal Bilimler Enstitüsü Dergisi, 16(4), 559-585. 
DOĞAN, S., \& KILIÇ, S. (2007). Örgütsel Bağl1lığın Sağlamasında Personel Güçlendirmenin Yeri Ve Önemi. Erciyes Üniversitesi İktisadi ve İdari Bilimler Fakültesi Dergisi(29), 37-61.

ERKUŞ, A., \& FINDIKLI, M. A. (2013). Psikolojik sermayenin iş tatmini, iş performansı ve işten ayrılma niyeti üzerindeki etkisine yönelik bir araştırma. Istanbul University Journal of the School of Business Administration, 42(2).

ERKUTLU, H. V. (2015). Pozitif örgütsel davranış. Ankara Akademisyen Kitabevi.

GOLEMAN, D. (2009). Emotional intelligence. Moscow.

GROTKOWSKİ, K., \& MILLER, S. A. (2019). Optimists or optimistic: Replication of a taxometric study on optimism. Journal of Research in Personality, 82, 103854.

KELEŞ, H. N. (2011). Pozitif Psikolojik Sermaye: Tanimi, Bileșenleri Ve Örgüt Yönetimine Etkileri. Organizasyon ve Yönetim Bilimleri Dergisi, 3(2), 343-350.

KUTANIS, R. Ö., \& YILDIZ, E. (2014). Pozitif Psikoloji İle Pozitif Örgütsel Davranış İlişkisi Ve Pozitif Örgütsel Davranış Boyutları Üzerine Bir Değerleme. Süleyman Demirel Üniversitesi Vizyoner Dergisi, 5(11), 135-154.

LUTHANS, F. (2002a). The need for and meaning of positive organizational behavior. Journal of Organizational Behavior: The International Journal of Industrial, Occupational and Organizational Psychology and Behavior, 23(6), 695-706.

LUTHANS, F. (2002b). Positive organizational behavior: Developing and managing psychological strengths. Academy of Management Perspectives, 16(1), 57-72.

LUTHANS, F., \& YOUSSEF, C. M. (2004). Human, Social And Now Positive Psychological Capital Management: Investing İn People For Competitive Advantage. Organizational Dynamics, 33 , 143-160.

LUTHANS, F., YOUSEFF, C. M., \& AVOLIO, B. J. (2007). Psychological Capital:Developing The Human Competitive Edge. New York: Oxford University Press.

MASTEN A.S., MORISON P., PELLEGRINI D. \& TELIEGEN A. (1990). Competence under stress: risk and protective factors. In J. Rolf, A. S. Masten, D. Cicchetti, K. H. Nuechterlein S. Weintraub (Eds.), Risk and protective factors in the development of psychopathology (pp. 236-256). New York: Cambridge University Press.

MASTEN, A. S. \& REED, M. G. J. (2002). Resilience in development. Handbook of positive psychology, 74, 88.

MOWDAY, R. T., STEERS, R. M., \& PORTER, L. W. (1979). The measurement of organizational commitment. Journal of vocational behavior, 14(2), 224-247.
SARIYILDIZ, A.Y. (2020). Örgütsel Bağll1ık ve İş Etiği. Ankara: Nobel Bilimsel Eserler, Birinci Basım, ISBN: 978-625-7173-58-2.

SEÇGIN, S. (2013). Pozitif Örgütsel Davranışın Örgütsel Bağlllık Üzerindeki Etkilerini Belirlemeye Yönelik Eskişehir Havacıllk Sektöründe Yapılan Bir Araştırma. (Yayınlanmamış Yüksek Lisans Tezi). Anadolu Üniversitesi, Eskișehir.

SCHEIER, M. F. \& CARVER, C. S. (1985). Optimism, coping, and health: assessment and implications of generalized outcome expectancies. Health psychology, 4(3), 219. Scheier, M. F., \& Carver, C. S. (1985). Optimism, coping, and health: assessment and implications of generalized outcome expectancies. Health psychology, 4(3), 219.

SELIGMAN, M. E. (1998). Positive Psychology, Positive Prevention, And Positive Therapy. Handbook of positive psychology, 1(1998), 3-12.

STAJKOVIC, A. D., \& LUTHANS, F. (1998). Self-efficacy and work-related performance: A meta-analysis. Psychological bulletin, 124(2), 240

STUP, R. E. (2006). Human resource management, organizational commitment, and perceived organizational support in dairy farm businesses. The Pennsylvania State University.

TÖSTEN，R. \& ÖZGAN，H. (2017). Öğretmenlerin pozitif psikolojik sermayelerine ilişkin algılarının incelenmesi. Elektronik Sosyal Bilimler Dergisi, 16(62), 867-889. 